\title{
Managing the Classroom Environment-Friendly for Primary School Students
}

\author{
Sri Marmoah ${ }^{1}$, Jenny I S Poerwanti ${ }^{2}$ \\ \{marmuah@staff.uns.ac.id ${ }^{1}$, jenny_isp@staff.uns.ac.id $\left.{ }^{2}\right\}$ \\ 1,2Universitas Sebelas Maret, Surakarta, Indonesia
}

\begin{abstract}
Environmentally friendly education plays an integral role in basic education, especially in students' development. This study aims to analyze the role of teachers in the management of environmentally friendly classes and management of environmentally friendly classes to support the implementation of learning in elementary schools in Jambi City. The design of this study uses a qualitative approach. The place of this study is located in a public elementary school with a total of 41 participants with 98 elementary school teachers in Jambi. The selection of subjects used cluster random sampling strategy. Data obtained through observation, interviews, questionnaires, and documentation. Data analysis techniques used was interactive analysis with stages of reduction, presentation, and conclusion. The result showed that the teacher had five roles used in the teachinglearning process, including inclusive students, effective learning, students who were healthy and protected, sensitive to gender, and involved with children and the teacher has managed the class through activities of planning, implementation, and evaluation in the teaching-learning process.
\end{abstract}

Keyword: classroom environment, friendly, primary students

\section{INTRODUCTION}

Law of the Republic of Indonesia number 20 of 2003 concerning the National Education System, article 1 reads "education is a process that is planned to create a learning environment so that students have personality, intelligence, character, and skills that are useful for themselves, society, nation, and country" [1]. The statement means that education is a place for children to develop which is important to maximize. Environmentally friendly education plays an integral role in basic education, especially in the development of students.

Regular frequency of learning will affect the academic and social success of students [2]. Eco-friendly education can be demonstrated by adequate facilities, comfortable classrooms, and clean learning environments so as to stimulate children's learning interest. The learning environment implies buildings, rooms, tools, equipment, and facilities for teaching, while the social environment includes the level of interaction between students and teachers, learning materials with students, and teachers with learning materials [3]. Achieving expectations of implementing environmentally friendly education is still rarely done in various schools. Some cases show that there is a fundamental conflict between the ecological system and human culture that cannot coexist with natural organisms, such as plants and the surrounding environment [4]. Furthermore, the results show that $25 \%$ of schools have not implemented environmentally friendly education for children because schools do not have infrastructure facilities such as toilet facilities, chairs, tables, and most classrooms are not friendly to students with disabilities [5]. 
Furthermore, there is an imbalance of teachers who teach about environmental education [6]. The results of the study meant that environmentally friendly education in elementary schools had not fully gone as expected.

These problems must be addressed immediately. Teachers, principals, and the environment are external factors that greatly influence the environmentally friendly education process [7]. This study reveals that institutional/school support and teacher monitoring of student learning, ECED learning experience, and knowledge of pedagogical content play an important role in the development of environmentally friendly education and teaching practices [8].

The role of the school is equated with managing schools to be more environmentally friendly. Schools should make the classroom environment interesting and fun for students so that, the teachers can increase their productivity in teaching. The results of other studies indicated that there were significant differences in the strategies applied in the management of the school environment, namely the management of the school environment has a significant effect on learning habits and management of the school environment has a significant effect on the quality of the school environment [9]. Furthermore, elementary school students have a good understanding of the pillars of nature, social and ego in school development, although there are differences in students' understanding of each class on environmentally friendly issues and this study reveals that school accreditation does not significantly affect students in understanding environmentally friendly problems [10]. The results of an investigation of the characteristics of a metacognitive oriented learning environment showed an association with mind-friendly class characteristics based on the opinions of middle school students, especially in science classes with $53 \%$ of the total variance with details: $57 \%$ of teacher behavior promotes thinking; $39 \%$ of student behavior increases thinking; and $6 \%$ about preventive thinking behavior [11].

Previous research was limited to the effects of environmentally friendly learning on school quality and did not explain the management of the school environment in detail, both from class management and infrastructure. Some previous studies only looked for influences and relationships related to general child-friendly environmental education and not carried out in Jambi city. However, this study examined more deeply the teacher's role in managing environmentally friendly classes for elementary school students including the classroom environment and facilities, and environmentally friendly classroom management to support the implementation of learning in elementary schools in Jambi.

\section{METHOD}

This study aimed to analyse eco-friendly classes for students in elementary schools. The design of this study is qualitative research. The design of this study was qualitative research. Qualitative research is exploring and understanding everybody or groups that describe about social or human problems [12]. Qualitative research addresses one person or group about social or human problems [12]. This research was conducted in 41 public elementary schools in Kota Baru, Jambi. The subjects in this study were 98 elementary school teachers in Jambi City. Data was collected through observation, questionnaires, interviews, and documentation. Data analysis techniques used was interactive analysis with stages of reduction, presentation, and conclusion. 


\section{RESULT AND DISCUSSION}

\subsection{Teacher's Role in Classroom Environment-Friendly}

The results were obtained from the observation and interview result and followed by discussion. The data from that instrument are discussed in the finding and discussion below. The table below showed the observation result of teachers' role in managing the classroom environment. The observation sheet consists of five items.

Table 1. Summary of Distribution of The Teacher's Role in The Classroom Environment-Friendly

\begin{tabular}{lcccc}
\hline \multirow{2}{*}{ Question on Teachers' Role } & \multicolumn{2}{c}{ Average Teachers' opinion in favor of } & \multirow{2}{*}{ Total } \\
\cline { 2 - 4 } & Frequency & Yes & No \\
\hline Inclusive of Children & Frequency & 40 & 1,0 & 41 \\
& Percents & 97.5 & 2.5 & $100 \%$ \\
Effective for Learning & Frequency & 39 & 2,0 & 41 \\
Healthy \& Protective & Percents & 95.1 & 4,9 & $100 \%$ \\
& Frequency & 38 & 3 & 41 \\
Gender Sensitive & Percents & 92.7 & 7.3 & $100 \%$ \\
Involved with Children & Frequency & 41 & 0,0 & 41 \\
& Percents & 100 & 0.0 & $100 \%$ \\
Average & Frequency & 39 & 2.0 & 41 \\
\hline
\end{tabular}

The teachers played an inclusive role for children so that learning is carried out effectively, protects children, is gender sensitive, and establishes harmonious relationships with children, families, and communities. From the table above, it showed that the teacher's inclusive role is not to exclude, not discriminate; provide free education; respect differences; ensuring equal learning for all children in the class; respond to diversity; meeting the needs of children.

\subsection{Managing the Classroom Environment-Friendly}

In collecting the data, the researcher used questionnaire. The questionaire was done to answer the research questions. These are the result of the questionnaire that had been conducted for elementary teachers in Kota Baru, Jambi

Table 2. Managing The Classroom Environment Friendly

Average Teachers' opinion in favor of

Question on Managing Classroom

Total

Frequency $\quad$ Yes $\quad$ No




\begin{tabular}{|c|c|c|c|c|}
\hline Planning & & & & \\
\hline \multirow[t]{2}{*}{ Making Syllabus } & Frequency & 40 & 1,0 & 41 \\
\hline & Percents & 97.5 & 2.5 & $100 \%$ \\
\hline \multirow[t]{2}{*}{ Making lesson plan } & Frequency & 39 & 2,0 & 41 \\
\hline & Percents & 95.1 & 4,9 & $100 \%$ \\
\hline \multirow[t]{2}{*}{ The arrangement of teaching media } & Frequency & 38 & 3 & 41 \\
\hline & Percents & 92.7 & 7.3 & $100 \%$ \\
\hline \multicolumn{5}{|l|}{ Actuating } \\
\hline \multirow[t]{2}{*}{ Checking Attendance } & Frequency & 41 & 0,0 & 41 \\
\hline & Percents & 100 & 0.0 & $100 \%$ \\
\hline \multirow[t]{2}{*}{ Collecting the students' work } & Frequency & 39 & 2.0 & 41 \\
\hline & Percents & 95,1 & 4,9 & $100 \%$ \\
\hline \multirow{2}{*}{$\begin{array}{l}\text { Distributing of materials } \\
\text { and equipment }\end{array}$} & Frequency & 40 & 1,0 & 41 \\
\hline & Percents & 97.5 & 2.5 & $100 \%$ \\
\hline \multirow{2}{*}{$\begin{array}{l}\text { Gathering the information from } \\
\text { students }\end{array}$} & Frequency & 39 & 2,0 & 41 \\
\hline & Percents & 95.1 & 4,9 & $100 \%$ \\
\hline \multirow[t]{2}{*}{ Recording of data } & Frequency & 38 & 3 & 41 \\
\hline & Percents & 92.7 & 7.3 & $100 \%$ \\
\hline \multirow[t]{2}{*}{ Maintaining files } & Frequency & 40 & 1,0 & 41 \\
\hline & Percents & 97.5 & 2.5 & $100 \%$ \\
\hline \multirow[t]{2}{*}{ Presenting the learning material } & Frequency & 39 & 2,0 & 41 \\
\hline & Percents & 95.1 & 4,9 & $100 \%$ \\
\hline \multirow[t]{2}{*}{ Giving the task or homework } & Frequency & 38 & 3 & 41 \\
\hline & Percents & 92.7 & 7.3 & $100 \%$ \\
\hline \multicolumn{5}{|l|}{ Evaluating } \\
\hline \multirow[t]{2}{*}{ Survey from vice of headmaster } & Frequency & 40 & 1,0 & 41 \\
\hline & Percents & 97.5 & 2.5 & $100 \%$ \\
\hline \multirow[t]{2}{*}{ Survey from headmaster } & Frequency & 39 & 2,0 & 41 \\
\hline & Percents & 95.1 & 4,9 & $100 \%$ \\
\hline \multirow[t]{2}{*}{ Survey from supervisor } & Frequency & 38 & 3 & 41 \\
\hline & Percents & 92.7 & 7.3 & $100 \%$ \\
\hline Average & $\mathrm{F}$ & 39.14 & 41 & $100 \%$ \\
\hline
\end{tabular}


Information in table 2 explained managing the classroom environment-friendly in planning indicate that majority $39(95.1 \%)$ of the respondents were in agreement that their planning consists of making syllabus, making a lesson plan, and arrangement of teaching media. This was followed by $2(4.9 \%)$ respondents who disagreed their planning consist of making syllabus, making a lesson plan, and arrangement of teaching media. This means that large amount (39 or $95.1 \%$ ) of the elementary school teachers in the research areas are involved in a planning of the managing classroom. This clearly showed that many elementary school teachers in Kota Baru, Kota Jambi practiced in the planning that consists of making syllabus, making a lesson plan, and arrangement of teaching media.

Information about actuating divided by checking attendance, collecting the students' work, distributing of materials and equipment, gathering the information from students, recording of data, maintaining files, presenting the learning materials, and giving homework, reveals that $39.25(95.71 \%)$ elementary teachers were in agreement that their actuating while $1.75(4.28 \%)$ teachers were in disagreement in their opinions on the asked question about actuating.

The overall results about evaluating consist of the survey from the vice of the headmaster, survey from the headmaster, and survey from the supervisor, indicate that 39 (95.1\%) respondents were in agreement in the opinions on the view of actuating in the classroom environment-friendly while $2(4.9 \%)$ respondents disagreed. This indicates that elementary school teachers in the region are evaluated by their managing classroom as indicated by $95.1 \%$ agreeing teachers' opinions respectively. This means that survey from vice of the headmaster, survey from the headmaster, and survey from the supervisor are almost equally practiced by elementary school teachers in Kota Baru, Kota Jambi. In this research, there are 14 questions that the researcher used to construct the interview with the elementary teachers in Kota Jambi. Based on the result of the interview with the elementary teachers at Kota Jambi the result showed that the elementary teachers used many roles in classroom environment especially in child-friendly.

\footnotetext{
"The situational factor affecting child protection in school consisting of physical, verbal, and psychological. Convenience school, of course, can protect the children. For example, physically, facilities, and infrastructures. Completed and qualified facilities and infrastructures can make the children study happily and in a long period. Besides that, it can make the students be safe in school in any situation. Verbal action needed in the friendly school, without verbal action, it cannot be built, for example, when the students talk or speak impolitely, the teachers and all staff in that school must remind him/her to speak politely. Psychologically, it the school environment is safe in all area, of course, the students or children might be happy in school to study, to do all school activities."
}

Based on the findings of this study, the role of teachers in classroom management as inclusive for children also looks better when teachers designed class. Meanwhile, it is equally effective for learning too, because each teacher uses a variety of models and diverse learning strategies so students are happy to learn. Class management that is played well by the teacher will affect the learning conditions of students. The application of the model along with technology media is an important part of learning [13].

The teacher has the role of providing effective learning services through learning content, provision of materials and resources, capacity, morals, commitment from all elements of the school. Teachers are actors who can influence students to consciously care about the environment [4]. Learning will be more fun and attached to the hearts of students with maximum service. 
The teacher's role in healthy and protecting children is done by ensuring a healthy, hygienic and safe learning environment; provide life skills based health education; help defend and protect all children from abuse and danger; promote physical and psycho-social-emotional health of teachers and students; and provide positive experiences for students. Schools play an important role in making education policies regarding student health so that the public as customers increasingly trust the school [14].

Teachers as people who are gender sensitive have a role to promote gender equality; guarantee friendly facilities; eliminate gender stereotypes; giving rights, dignity and equality to students. Finally, teachers must be involved with children, families, and communities by promoting child-centered children's participation in all aspects of school life; become the primary caregiver and child educator; build harmonious relationships between children, parents and teachers. The development of the practice of gender sensitivity between teachers and parents is based on father involvement and harmonious relations with mothers [15].

Starting from the discovery of eco-friendly classroom management, elementary school teachers always manage their classes; in planning consist of making syllabi, making lesson plans, and arranging teaching media. Class management is intended to provide opportunities for students to learn all things by organizing students, space, time, and materials so that student learning can occur [16]. Meanwhile, in actuation consists of checking attendance, collecting student work, distributing materials and equipment, collecting information from students, recording data, maintaining files, presenting learning materials, and providing homework. Class management relates to all the things teachers do to organize students, settings, time, and material so that student learning can be effective and meaningful [17]. Teachers have the potential to become important socialization agents for students by using learning styles that are appropriate for students and improving student learning achievement through structural assignments [18]. The survey activity was implemented so that teachers maximize learning better by taking effective steps [17]. All school residents must work together so that the evaluation is in accordance with school expectations.

From the description above, it can be concluded that the implementation of environmentally friendly classroom management is carried out in three ways, namely planning through activities to make syllabus, planning learning, and using learning media; implementation through checking student attendance, registering student work, distributing learning materials and equipment, organizing information from students, recording data, repairing files, presenting learning materials, and giving homework; and evaluation through a survey of principals, supervisors, and vice principals.

\section{CONCLUSION}

Based on the discussion above, then there are two things that could be concluded from this study. The teachers have used five roles in the teaching-learning process, namely: teaching children in an inclusive manner, streamlining learning, nourishing and protecting children, being sensitive to gender, and engaging with children. The management of environmentally friendly classes that have been carried out by teachers includes: planning through syllabus activities, planning learning, and using learning media; implementation through checking student attendance, registering student work, distributing learning materials and equipment, organizing information from students, recording data, repairing files, presenting learning materials, and giving homework; and evaluation through a survey of principals, supervisors, and vice principals. 


\section{REFERENCES}

[1] Government of Republic of Indonesia, "Act of the Republic of Indonesia on National Education System 1," System, no. 20, pp. 1-58, 2003.

[2] E. A. Shewark, K. M. Zinsser, and S. A. Denham, "Teachers' Perspectives on the Consequences of Managing Classroom Climate," Child Youth Care Forum, vol. 47, no. 6, pp. 787-802, 2018.

[3] A. Nwanekezi and B. Iruloh, "Assessing Learning Environment for Achieving Standard in Primary Education: Implication for Counselling for Human Capacity Development," African Res. Rev., vol. 6, no. 2, pp. 274-289, 2012.

[4] S. CANDAN and S. ERTEN, "Pre-Service Teacher Opinions About Eco-Friendly Person Activity Package Developed to Raise Environmental Awareness," Int. Electron. J. Environ. Educ., vol. 5, no. 2, pp. 62-85, 2015.

[5] L. M. O’Brennan, C. P. Bradshaw, and M. J. Furlong, "Creating a Friendly School Learning Environment for Nigerian Children," Eur. Sci. J. April Ed., vol. 6, no. 2, pp. 125-136, 2014.

[6] M. K. Casey and R. K. Gable, "Beginning teachers ' perceptions of preparedness to differentiate instruction for diversel earners," Northeast. Educ. Res. Assoc., 2011.

[7] A. Hermino, "Child-Friendly School in Educational Settings for Elementary School in the Papua Island of Indonesia,” vol. 17, no. 1, 2017.

[8] K. F. Murtaza, "Developing Child Friendly Environment in Early Childhood Education Classrooms in Pakistan," Int. J. Acad. Res. Bus. Soc. Sci., vol. 1, no. 3, p. 11, 2012.

[9] L. B. Obong, S.-M. Okey, and L. A. Okaba, "Strategies for School Environmental Management in Nigerian Secondary Schools: A Case of Calabar, Nigeria," Int. Educ. Stud., vol. 3, no. 1, pp. 196-205, 2014.

[10] B. Prabawani, I. M. Hanika, A. Pradhanawati, and A. Budiatmo, "Primary Schools EcoFriendly Education in the Frame of Education for Sustainable Development," Int. J. Environ. Sci. Educ., vol. 12, no. 4, pp. 607-616, 2017.

[11] Ş. A. Şahin, "The Extent to Which the Characteristics of a Metacognitive Oriented Learning Environment Predict the Characteristics of a Thinking-Friendly Classroom," Eurasian J. Educ. Res., vol. 15, no. 60, pp. 241-260, 2015.

[12] D. Ortiz, "Research Design: Qualitative, Quantitative, and Mixed Methods Approaches [Book Review]," Qual. Res. J., vol. 6, no. 2, p. [205]-207, 2009.

[13] M. H. Abdel Rahman Ibrahim, "Classroom Management The Effectiveness of Teacher's Roles," Educ. Linguist. Res., vol. 2, no. 1, p. 69, 2016.

[14] R. A. Hahn and B. I. Truman, "Education improves public health and promotes health equity," Int. J. Heal. Serv., vol. 45, no. 4, pp. 657-678, 2015.

[15] N. Polovina, "Parent-School Cooperation as a Gender Sensitive Practice," Int. J. about Parents Educ., vol. 7, no. 2, pp. 91-99, 2013.

[16] K. Sieberer-Nagler, "Effective Classroom-Management \& Positive Teaching," English Lang. Teach., vol. 9, no. 1, p. 163, 2015.

[17] S. Demirdag, "Self - Assessment of Middle School Teachers :," Int. J. New Trends Educ. their Implic., vol. 6, no. 2, pp. 45-55, 2015.

[18] D. Barni, C. Russo, and F. Danioni, "Teachers' values as predictors of classroom management styles: A relative weight analysis," Front. Psychol., vol. 9, no. OCT, 2018. 